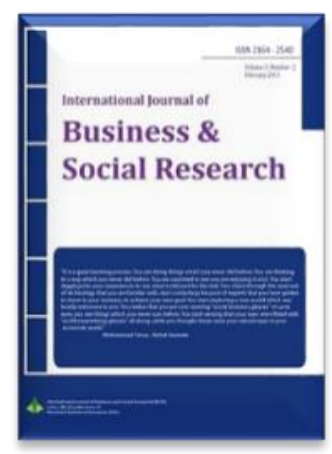

\title{
A Comparative Study on Factors Affecting Consumer's Choice on Purchasing a Cellular Phone across India \& US
}

\author{
Jyotirmoy Samanta ${ }^{1}$, Neelotpaul Banerjee ${ }^{2}$
}

\begin{abstract}
In the hasty budding plethoric technological space, mobile technology \& devices play a noteworthy role. It's imperative to take a cognizance of the fact that mobile market is contributing substantially to global economy as well as to an individual nation's economy. Mobile devices market is predominantly consumer driven \& this research work emphasizes on cross national comparative study among mobile consumers across India \& USA. The study focuses on a thirty leading factors that influence consumers principally in their buying decision making process. An empirical survey of four hundred consumers was conducted across India \& USA using a questionnaire. The study reveals that 'Price' is the pivotal factor that an Indian consumer considers at first place whereas an American buyer stresses upon 'Brand Name'. Furthermore, it unveils that a US consumer looks for 'EMI options' for buying while Indian consumers concentrates on 'Design of the device'. This study will aid mobile manufacturing firms to frame effective marketing strategies \& help marketing managers to design effective marketing communications.
\end{abstract}

Keywords: Bayesian classifier, Cellular phone, Consumer, India, USA.

Available Online: 06-07-2016.

This is an open access article under Creative Commons Attribution 4.0 License, 2016.

\subsection{INTRODUCTION}

Mobile phone usage \& its market size has grown tremendously in the past 40 years since its inception. With rapid augmentation of the telecommunication industry there 's a hasty innovation in technology related to mobile devices. In modern history technology adoption rates, its mobile phone that has fastest embracement rates in household (Comer and Wikle 2008). Mobile phone usage has helped significantly in information sharing using communication technology thus contributing myriad growth rate in global business perspective. Hence, in today's world cellular phones play a pivotal role among consumers in developed \& developing countries and its economies. India being a developing economy has roughly a market size near to 933 million mobile users currently per TRAI in March 2014. Likewise, the US wireless industry itself is valued nearly $\$ 195$ billion (CTIA July 2012). Hence, it is a point of disquiet

${ }^{1}$ Corresponding Author. Department of Management Studies, National Institute of Technology, Durgapur-713209, West Bengal, India. E-mail: jyotirmoysamanta@hotmail.com

2 Department of Management Studies, National Institute of Technology, Durgapur-713209, West Bengal, India. 
to come across consumer buying decision process \& shade thrust on the factors that ultimately decide consumer choices between different mobile phone brands. To understand what factors drives a consumer to choose and buy a mobile phone is thus a vital arena to be researched on, henceforth this topic was chosen to get a better insight. It also evident, that global manufacturing firms always want to find out apposite reasons that triggers in consumer mind frame that influences the buying decision. There are supplementary questions that raise inquisitiveness in the mind of academic researchers on the comparing different factors vide similar studies in two bigger size markets like India \& USA albeit US being developed and India is still developing economic market. Amidst this various questions mix the search is chosen to address suffice this.

The world being a global village has big manufacturers catering in both these globalized nations of India and US. It's imperative to study the factors influencing consumer decision making process. The current study would assist the brand managers of various global telecom firms in framing strategies to be delved into, henceforth implementing them to build on various efficient marketing communications to target consumers across India \& US. It would also aid up in designing \& manufacturing products precise to each of this nations looking into customers purchasing decision perspective. Furthermore, this study will add on in building a platform in existing academic literature wherein comparative studies across India \& US is limited to come across.

\subsection{LITERATURE REVIEW}

There are quite a number of studies that are being conducted in the past on consumer perspective in buying a mobile phone or a cellular device. Brief synopses of those studies are listed here in below: Considering marketing point of view, consumer choice can be studied through the classical five-step (need--information-search--evaluation of alternatives-purchase--post-purchase evaluation) problem solving paradigm or through the progression of consumer choice from a product class to brand choice (Dorsch, Grove, and Darden, 2000). Hence, consumers have limited choice for an alternative \& rely more on preconceived preferences.

Karjaluoto, Karvonen (2005) studied the different factors that determines consumers choice to buy a new mobile handset $\&$ reasons for changing an existing mobile device to a new one. They concluded that innovative services, multimedia, design, brand and basic properties, outside influence, price, and reliability are prime factors that consumers look for.

Jhangiani, Tonya Smith-Jackson (2007) investigated cross-cultural differences \& resemblance of user preferences of cell phone characteristics. Product interactive focus groups were conducted across India and in the United States; groups included users without any apparent disabilities and users with a visual disability of legal blindness. They considered ideological, psychological, sociological \& physiological that needs to be taken care while designing a cell phone across these two countries. The study spanned across cultural differences and its prevailing importance as well. Madden, Lenhart, Duggan (2013) researched that $78 \%$ of American teens own a mobile set $\&$ almost half ( $47 \%$ ) of these young people has smartphones. This constitutes into almost $37 \%$ of all teens who have smartphones, raised from $23 \%$ in 2011.

Smith (2011) on his research work titled 'Americans and their cell phones' find how 51\% of an American Adult finds useful in information finding through cell phone. Supplementary, how mobile phone are vital in handling emergency situation or escaping boredom to an average American is emphasised through the research work. Nelisen (2013) did a detailed study \& published a mobile consumer report. The report highlighted how good design, operating system, value for money are important which consumers look forward while choosing a cell phone.

In a mobile research conducted across Portland, United States by Michael, McGregor, Allen (2008) highlighted across the significance of Global Positioning system across cell phones in tracking user's 
outdoor activities and its implication to trust upon on emergency needs. It also implied the future scope for user's preference towards GPS enabled phones in USA as a preferred choice while buying one.

Chua, Balkunje, Goh (2011) in a theoretical research in mobile information fulfilment need conducted focus on three main categories, first, it focuses on factors affecting users' perceptions and actual fulfilment. Secondly, it identifies technical/functional parameters of cell phones which influence fulfilment. Finally, it investigates how contextual factors trigger information needs and affect fulfilment. Yuan, Xu, Chung (2014) proposed a phone interest model based on web statistics. Since mobile phone users change cell phone often, mobile phone advice system is of great significance for mobile operator to attain business advantage. There are necessary challenges for researchers to design such system. From the study factors in context to application behaviour like searching, browsing, chatting etc. were considered.

Cui, Chipchase, Ichikawa (2007) did a cross cultural study on phone carrying by an individual and personalization henceforth and emphasized on Non-instrumental attributes include: identity, sociability, and aesthetics. They figured some cultural differences ranging from the prevalence of cases, straps, and other physical cell modification to other ways to personalize and guard the look of the phone. Phone straps and decorative stickers were more prevalent in cities while they differed in other cultures.

Vincent (2009) studied the importance of emotions and built in a relationship amidst difference people and their increasing emotional attachment toward this small device and how cellular phones are getting attached to human lives. The study revolved around UK people base. Hong, Thong, Moon (2008) concluded that mobile data services are getting popular subsequently increase mobile markets \& influencing mobile purchasing inquisitiveness among consumers.

Although there had been several work in the past but it can be concluded from existing literature review that there had not been much work in comparing consumer's choices across India \& US as far as mobile handset purchase is concerned. This current study would be significant enough to fill this void and be a platform for future researchers and mobile producing companies to better understand the differences and similarity among consumers in both the countries. This would certainly add on business growth rate keep an eye on consumer's choice.

\subsection{RESEARCH METHODOLOGY}

A through empirical investigation is to be considered at the outset on the basis of factors considered via various existing literature available and author's add-on. Prior to conducting a final survey, a pilot survey is done with a sample size of 25 in India. Subsequently, a sample size of 25 was considered from dummy online survey done in US initially. After that the questionnaire was updated accordingly for a final one. The final survey was considered with sample size of 200 each in India and USA. US survey was done through online based survey where in Indian survey compromised with interview among urban cities of West Bengal. Likert scale in a range of 1-5 weight is used for taking inputs for the survey.

Joubert and Kriek (2009) articulated the fact that the opening of educational and psychological assessment in web based surveys or online surveys as it may be so called has given it a scope to increase radically. Perkins (2004) adjoins that web based surveys comprises of information science, colleges and universities, secondary school education, personnel and other applied settings and, of course, the general survey and survey research industry. Hogg (2003), almost a decade ago studies and concluded that almost $\$ 500$ million was spent on web based surveys in the USA alone. Research report by Harvard Business Review (2010) named The New Conversation: Taking Social Media from Talk to Action discussed the role of 'adoption of social media' as an important \& relevant part of online survey techniques in getting accurate reviews from consumers. Hence, for technology suited market like US online market was used. An interview based classic survey was considered in India based on easy access of people by author in India. 
For the web based survey in US, the questionnaire was uploaded to a customized survey portal. The region or geography was confined to US (NorthEast, MidWest, South \& West) using 'Geography restriction' methodology using IP restriction methods in these particular cases. Additionally, the web based portal with questionnaire were promoted via social networking portals and the survey was confined to only US.

A detailed study of existing literatures available is done and on basis of that and adding authors own contributed parameters, a net of 30 factors are considered. Factor that had incorporated mobile culture (Hansen, 2003) were considered like (a) communication services such as voice, text and pictures, (b) wireless Internet services such as browsing, corporate access and e-mail, and (c) different media services such as motion pictures, games and music. Riquelme (2001) research was built upon six key attributes (telephone features, connection fee, access cost, mobile- to-mobile phone rates, call rates and free calls) related to mobile phone purchasing respondents had to importance rate. The rest of the factors as mentioned in below were authors self-considered parameters based on interaction will people and per consumer psychology they are, (1) Stylish Design (2) Good operating system (3) Price of the handset (4) Price of accessories (5) Easy to use (6) Wide choice of applications (7) Available options for mode of buying (8) Quality of speaker (9) Camera quality (10) Quality of keypad/touch screen (11) Wi-fi, 3G, 4G facility (12) Email facility availability (13) Accessories given while buying (14) Advertisement of the brand (15) EMI options with mobile company brands (16) Previous buyers influence (17) Friend \& Family influence (18) Battery life (19) Availability of GPS services (20) Quality of Web browsing facility (21) Quality of online video streaming (22) Durability (23) Multi-tasking (24) Storage space (25) Facility for dual SIM (26) Tagged with telephone service provider (27)Brand name (28) Status symbol (29) Service centre availability (30) Discount. Samples included individuals of 18 years of age and above, from both the sexes with access to disposable income, owning a cell. The data collected were analysed using open source software WEKA 3.6.

The analysing Model is based on naïve Bayesian Classifier which takes in input a standard dataset to which it references to determine the proximity/distance from the standard dataset. It is a simple probabilistic classifier based on applying Bayes' theorem with strong (naive) independence assumptions. It assumes that the presence (or absence) of a particular feature of a class is unrelated to the presence (or absence) of any other feature, given the class variable. The closeness of proximity from standard dataset determines the value of $\mathrm{P}$-factor ( $(0)$. If we define the standard dataset as "Good", then the P-Factor (generated through our model) determines the closeness of the data to the standard data set. The higher the value of the P-Factor, the better is the factor.

Let us consider the following training data set to determine the criteria for considering a criterion (question/factor) to be good.

\begin{tabular}{lrrrrr}
\hline & $\mathrm{A}(2)$ & $\mathrm{B}(1)$ & $\mathrm{C}(0)$ & $\mathrm{D}(-1)$ & $\mathrm{E}(-2)$ \\
& 0 & 0 & 0 & 0 & 200 \\
& 0 & 0 & 0 & 200 & 0 \\
& 0 & 0 & 200 & 0 & 0 \\
& 0 & 0 & 0 & 55 & 60 \\
& 0 & 0 & 0 & 40 & 40 \\
& 0 & 0 & 0 & 70 & 80 \\
Mean & 10 & 10 & 30 & 10 & 20 \\
Variance & 0.62 & 0.62 & 16.54 & 30 & 30 \\
& 3.44 & 3.44 & 1214 & 1136.11 & 1136.11 \\
Mean: $\mu=\frac{}{n} \sum_{i=1}^{n} a_{i}$ & & & & &
\end{tabular}

If the random variable $\mathrm{X}$ is discrete with probability mass function $\mathrm{x} 1 \mapsto \mathrm{p} 1 \ldots \mathrm{xn} \mapsto \mathrm{pn}$, then 
$\operatorname{Var}(X)=\sum_{i=1}^{n} p_{i} \cdot\left(x_{i}-\mu\right)^{2}$

where, $\mu$ is the expected mean value i.e.,

$$
\mu=\sum_{i=1}^{n} p_{i} \cdot x_{i}
$$

Let us consider a result sample to be X. Plotting it to the Gaussian distribution, with the probability distribution function, we get,

$f\left(x ; \mu, \sigma^{2}\right)=\frac{1}{\sqrt{2 \pi \sigma^{2}}} e^{-(x-\mu)^{2} /\left(2 \sigma^{2}\right)}=\frac{1}{\sigma} \phi\left(\frac{x-\mu}{\sigma}\right), \quad x \in \mathbb{R}$.

To decide if a criterion (question/factor), say $\mathrm{T}$, is already good, we use,

$P(T \mid G O O D)=f\left(x_{T} ; \mu_{T} ; \sigma_{T}^{2}\right)$

We define a factor of an observation $\mathrm{O}$, as,

P-Factor $(O)=N_{A} *_{2} * f\left(x_{A} ; \mu_{A} ; \sigma_{A}^{2}\right)+N_{B} *_{1} * f\left(x_{B} ; \mu_{B} ; \sigma_{B}{ }^{2}\right)+N_{C} * O * f\left(x_{C} ; \mu_{C} ; \sigma_{C}{ }^{2}\right)+N_{D} *_{-1} * f\left(x_{D} ; \mu_{D} ; \sigma_{D}{ }^{2}\right)+$ $N_{E}^{*}-2 * f\left(x_{E} ; \mu_{E} ; \sigma_{E}^{2}\right)$

where $N_{x}(X=A, B, C, D, E)=$ Percentage Observation of the rating $A, B, C, D, E$

(A-Extremely Important, B-Important, C-Can't Say, D-Unimportant, E-Not at all important).

From the definition of P-Factor (O) it can be found that higher the value of P-Factor (O) better is the criterion.

The concept of information gain using ID3 (Iterative Dichotomiser 3) decision tree model is used to try figure out the demographic attributes and its implications on the factors affecting the sale of mobile phone. The rank of each of the factors is figured out by Bayesian classifier and the most important 5 factors are selected. Now, cluster each demographic attribute, based on the ranks denoted by each person on each of the selected factors and calculate the information gain for each of the demographic attribute.

Information gain $I G(A)$ is the measure of the difference in entropy from before to after the set $S$ is split on an attribute $A$. In other words, how much uncertainty in $S$ was reduced after splitting set $S$ on attribute $A$.

$$
I G(A, S)=H(S)-\sum_{t \in T} p(t) H(t)
$$

Where,

$H(S)$ - Entropy of set $S$

$T$ - The subsets created from splitting set $S$ by attribute $A$ such that $S=\bigcup_{t \in T} t$

$p(t)$ - The proportion of the number of elements in $t$ to the number of elements in set $S$

$H(t)_{\text {- Entropy of subset } t}$

In ID3, information gain can be calculated (instead of entropy) for each remaining attribute. The attribute with the largest information gain is used to split the set $S$ on this iteration. Finally, analyse the relationship of the demographics attributes using above ID3 to each of the 5 important factors found by Bayesian classifier and derive results.

\subsection{RESULTS AND DISCUSSIONS}


Various influencing factors are determined by analysing P-factor in US as well as in India. Table 1 illustrates that in case of US consumers the P-Factor $(O)=113.798$ are for Brand Value of mobile and ranked as 1. Then, comes the EMI options with mobile company brands with P-Factor $(O)=113.098$. Thirdly, Camera quality has P-Factor $(\mathrm{O})=90.0604$. The lowest in contrary, P-Factor $(\mathrm{O})=-89.79$ for Service centre availability for US consumers.

Table 1: P-factor derivation Bayesian classifier for US market

\begin{tabular}{|c|c|c|c|c|c|}
\hline Question & Strongly Agree & Disagree & $\begin{array}{l}\text { Strongly } \\
\text { Disagree }\end{array}$ & P-Factor & Rank \\
\hline Stylish Design & 28.4 & 11.58 & 6.29 & 83.1357 & 4 \\
\hline Good operating system & 28.4 & 22.63 & 13.5 & 46.0005 & 6 \\
\hline Price of the handset & 43.35 & 39.5 & 9.69 & 45.4346 & 7 \\
\hline Price of accessories & 42.35 & 38.5 & 8.69 & 44.4346 & 8 \\
\hline Easy to use & 14.94 & 4.85 & $17 \cdot 35$ & 39.5059 & 9 \\
\hline Wide choice of applications & 26.96 & 28.4 & 3.88 & 35.0419 & 10 \\
\hline Available options for mode of buying & 25.52 & 22.15 & 16.87 & 21.4696 & 11 \\
\hline Quality of speaker & 19.31 & 39.02 & 5.85 & -1.3183 & 12 \\
\hline Camera quality & 43.31 & 7.73 & 13.5 & 90.0604 & 3 \\
\hline Quality of keypad/touch screen & 18.31 & 38.02 & 4.85 & -2.3183 & 13 \\
\hline Wi-fi, 3G, 4G facility & 19.75 & 22.63 & 15.9 & -5.9824 & 14 \\
\hline Email facility availability & 10.62 & 34.65 & 13.98 & -11.337 & 15 \\
\hline Accessories given while buying & 24.08 & 43.79 & 23.6 & -34.424 & 16 \\
\hline Advertisement of the brand & 22.63 & 31.77 & 34.17 & -44.775 & 17 \\
\hline $\begin{array}{l}\text { EMI options with mobile company } \\
\text { brands }\end{array}$ & 39.46 & 2.92 & 7.25 & 113.098 & 2 \\
\hline Previous buyers influence & 11.58 & 11.58 & 41.38 & -49.234 & 18 \\
\hline Friend \& Family influence & $4 \cdot 4$ & 16.42 & 28.92 & -51.739 & 19 \\
\hline Battery life & 3.4 & 15.42 & 27.92 & -52.739 & 20 \\
\hline Availability of GPS services & 3.44 & 18.35 & 41.9 & -64.317 & 21 \\
\hline Quality of Web browsing facility & 2.44 & 17.35 & 40.9 & -65.317 & 22 \\
\hline Quality of online video streaming & 15.46 & 6.81 & 63.54 & -78.854 & 23 \\
\hline Durability & 14.46 & 5.81 & 62.54 & -79.854 & 24 \\
\hline Multi-tasking & 2.96 & 41.42 & 33.25 & -85.672 & 25 \\
\hline Storage space & 1.96 & 40.42 & 32.25 & -86.672 & 26 \\
\hline Facility for dual SIM & 4.33 & 1.96 & 25.04 & -87.788 & 27 \\
\hline $\begin{array}{l}\text { Tagged with telephone service } \\
\text { provider }\end{array}$ & 5.33 & 1.96 & 25.04 & -88.477 & 28 \\
\hline Brand name & 37.54 & 12.54 & 1.48 & 113.798 & 1 \\
\hline Status symbol & 25.52 & 22.15 & 16.87 & -88.588 & 29 \\
\hline Service centre availability & 26.96 & 28.4 & 3.88 & -89.79 & 30 \\
\hline discount & 48.6 & 16.87 & 14.46 & 68.1028 & 5 \\
\hline
\end{tabular}

Table 2 illustrates that in case of Indian consumers the P-Factor $(O)=112.59$ are for Price of the handset and ranked as 1. Then, comes the Stylish Design with P-Factor $(\mathrm{O})=111.89$. Thirdly, Battery life has PFactor $(\mathrm{O})=88.86$. The lowest P-Factor $(\mathrm{O})=-90.98$ is for Quality of keypad/touch screen. In contrary, PFactor $(O)=-89.79$ for Service centre availability for Indian consumers.

Both US and Indian consumers have common craze for 'Camera quality' wherein this is $3^{\text {rd }} \& 4^{\text {th }}$ most factor that customers consider while buying. 
Table 2: P-factor derivation Bayesian Classifier for US market

\begin{tabular}{|c|c|c|c|c|c|c|c|}
\hline Question & $\begin{array}{r}\text { Strongly } \\
\text { Agree }\end{array}$ & Agree & Neither & Disagree & $\begin{array}{l}\text { Strongly } \\
\text { Disagree }\end{array}$ & P-Factor & Rank \\
\hline Stylish Design & 38.46 & 46.63 & 6.73 & 1.92 & 6.25 & 111.8976 & 2 \\
\hline Good operating system & 9.62 & 25.96 & 17.79 & 33.65 & 12.98 & -12.537409 & 15 \\
\hline Price of the handset & 36.54 & 35.1 & 16.35 & 11.54 & 0.48 & 112.598495 & 1 \\
\hline Price of accessories & 13.94 & 44.23 & 21.63 & 3.85 & 16.35 & 38.305945 & 9 \\
\hline Easy to use & 23.08 & 4.81 & 6.73 & 42.79 & 22.6 & -35.624355 & 16 \\
\hline Wide choice of applications & 24.52 & 22.12 & 16.35 & 21.15 & 15.87 & -89.7876 & 29 \\
\hline $\begin{array}{l}\text { Available options for mode of } \\
\text { buying }\end{array}$ & 4.33 & 44.23 & 26.44 & 0.96 & 24.04 & -89.6765 & 28 \\
\hline Quality of speaker & 47.6 & 12.5 & 10.58 & 15.87 & 13.46 & 66.902798 & 5 \\
\hline Camera quality & 27.4 & 45.19 & 11.54 & 10.58 & 5.29 & 81.935723 & 4 \\
\hline Quality of keypad/touch screen & 25.96 & 11.54 & 32.21 & 27.4 & 2.88 & -90.9898 & 30 \\
\hline Wi-fi, 3G, 4G facility & 21.63 & 6.25 & 8.17 & 30.77 & 33.17 & $-45 \cdot 974721$ & 17 \\
\hline Email facility availability & 25.96 & 11.54 & 32.21 & 27.4 & 2.88 & 33.841864 & 10 \\
\hline Accessories given while buying & 18.75 & 5.29 & 39.42 & 21.63 & 14.9 & -7.18237 & 14 \\
\hline Advertisement of the brand & 24.52 & 22.12 & 16.35 & 21.15 & 15.87 & 20.269582 & 11 \\
\hline $\begin{array}{l}\text { EMI options with mobile } \\
\text { company brands }\end{array}$ & 27.4 & 34.62 & 3.85 & 21.63 & 12.5 & 44.800547 & 6 \\
\hline Previous buyers influence & 10.58 & 17.79 & 20.67 & 10.58 & 40.38 & -50.434286 & 18 \\
\hline Friend \& Family influence & 3.33 & 44.23 & 26.44 & 0.96 & 24.04 & -88.9876 & 27 \\
\hline Battery life & 42.31 & 33.65 & 4.81 & 6.73 & 12.5 & 88.860374 & 3 \\
\hline Availability of GPS services & 41.35 & 11.06 & 2.4 & 37.5 & 7.69 & 43.234648 & 8 \\
\hline $\begin{array}{l}\text { Quality of Web browsing } \\
\text { facility }\end{array}$ & $17 \cdot 31$ & 3.85 & 37.98 & 37.02 & 3.85 & -3.518273 & 13 \\
\hline $\begin{array}{l}\text { Quality of online video } \\
\text { streaming }\end{array}$ & 1.44 & 25.96 & 16.35 & 16.35 & 39.9 & -66.516931 & 22 \\
\hline Durability & 13.46 & $17 \cdot 31$ & 2.88 & 4.81 & 61.54 & -81.053571 & 24 \\
\hline Multi-tasking & 0.96 & 11.06 & $17 \cdot 31$ & 39.42 & 31.25 & -87.871661 & 26 \\
\hline Storage space & 2.4 & 9.13 & 47.12 & 14.42 & 26.92 & -53.939245 & 20 \\
\hline Facility for dual SIM & 42.35 & 9.06 & 1.4 & 38.5 & 8.69 & 44.234648 & 7 \\
\hline $\begin{array}{l}\text { Tagged with telephone service } \\
\text { provider }\end{array}$ & 18.31 & 1.85 & 36.98 & 38.02 & 4.85 & -2.518273 & 12 \\
\hline Brand name & 2.44 & 23.96 & 15.35 & 17.35 & 40.9 & $-65 \cdot 516931$ & 21 \\
\hline Status symbol & 14.46 & $15 \cdot 31$ & 1.88 & 5.81 & 62.54 & -80.053571 & 23 \\
\hline Service centre availability & 1.96 & 9.06 & 16.31 & 40.42 & 32.25 & -86.871661 & 25 \\
\hline discount & 3.4 & 7.13 & 46.12 & 15.42 & 27.92 & -52.939245 & 19 \\
\hline
\end{tabular}

\subsection{CONCLUSION}

The study delves different influencing parameters among mobile customers in US \& India. It can be implied from the study that Price of mobile set is the most important factor that an Indian consumer deems while purchasing a mobile phone. Wherein it's the 'Brand name' of mobile firm the US consumer prefers to stress upon. The outcome is well explicated from the fact that people in India look for cheaper handsets. On contrary, it's the 'brand value' of the brands that appeals to US consumers. 
In disparity the US consumers prefers in EMI option from mobile companies, whereas Indians prefer 'good design'. It is evident that EMI option among Americans is more feasible in their capitalistic market economy. In contrast good design caters emotional quotient in Indian consumer's mind-set.

The camera quality factor is the close factor in which both people of the countries get attracted to. This can be well clarified by the fact that people tend to be more aesthetic in nature. Hence it can be concluded that people in both the countries tend to be persuade emotion based factors in addition to functionality intended parameters. Hence the study will endow with rich source for mobile companies to design \& delivery more value driven mobile sets to consumers across India \& US. It will furthermore help the marketing managers to frame right strategy for effective marketing communications.

\section{REFERENCES}

Chua, Balkunje, Goh (2011), ACM Publisher, ICUIMC'11, February 21-23, 2011, Seoul, Korea.

Comer and Wikle, T. A. (2008), Worldwide diffusion of the cellular telephone, (1995-2005). The Professional Geographer, 60(2), 252-269.

Cui, Chipchase, Ichikawa, N. Aykin (Ed.): Usability and Internationalization, Part I, HCII 2007, LNCS 4559, pp. 483-492, 2007. ๑ Springer-Verlag Berlin Heidelberg 2007.

Dorsch, M. J., Grove, S. J., Darden, W. R., (2000) "Consumer intentions to use a service category", Journal of Services Marketing, Vol. 14 Iss: 2, pp.92 - 117.

Hansen, L. (2003). Service layer essential for future success. Ericsson Mobility World.

Heikki, Karjaluoto, Jari, Karvonen et al, (2005), -Factors Affecting Consumer Choice of Mobile Phones: Two Studies from Finland, Journal of Euro marketing, Vol. 14, No.3, pp.37-60.

Hogg, A. 2003. 'Web efforts energize customer research', Electronic Perspectives, SeptemberOctober: 81-83.

General article, (June), available at: http://www.ericsson.com/mobilityworld/sub/articles/other_articles/nlo3jun05

Joubert, T. \& Kriek, H.J. 2009. 'Psychometric comparison of paper-and-pencil and online personality assessments in a selection setting', South African Journal of Industrial Psychology, 35(1): 78-88.

Jhangiani, Tonya Smith-Jackson (2007) Comparison of mobile phone user interface design preferences: perspectives from nationality and disability culture, ACM, Mobility Conference'07, September 1012, 2007, Singapore.

Madden, Lenhart, Duggan (2013) 'Teens and Technology 2013’, Pewresearch centre, Berkman center for internet \& society at Harvard University.

Michael, McGregor, Allen Observing Outdoor Activity Using Global Positioning System-Enabled Cell Phones S. Helal et al. (Eds.): ICOST 2008, LNCS 5120, pp. 177-184, 2008. ๑ Springer-Verlag Berlin Heidelberg 2008

McGaughey, R. E., and Mason, K. H. "The Internet as a marketing tool," Journal of Marketing Theory and Practice (6) 1998, pp 1-11.

Perkins, G.H. 2004. 'Will libraries' web-based survey methods replace existing nonelectronic survey methods? Information Technology and Libraries, September: 123-126.

Se-Joon Hong \& James Y. L. Thong \& Jae-Yun Moon \& Kar-Yan Tam, Understanding the behavior of mobile data services consumers, Springer Science + Business Media, LLC 2008.

Smith (2011) Americans and their cell phones Pewresearch centre, link: http://pewinternet.org/Reports/2011/Cell-Phones.aspx

Vincent Affiliations, Emotion and the Mobile Phone A. Esposito and R. Vích (Eds.): Cross-Modal Analysis, LNAI 5641, pp. 28-41, 2009. ( S Springer-Verlag Berlin Heidelberg 2009.

Yuan, Xu, Chung B. Benatallah et al. (Eds.): WISE 2014, Part I, LNCS 8786, pp. 308-323, 2014, Springer International Publishing Switzerland 2014. 


\section{APPENDIX}

Table 7: Demographic data

\begin{tabular}{|c|c|c|}
\hline \multicolumn{3}{|l|}{ Gender } \\
\hline & India & USA \\
\hline Male & 140 & 150 \\
\hline Female & 60 & 50 \\
\hline Total & 200 & 200 \\
\hline \multicolumn{3}{|l|}{ AGE } \\
\hline & India & USA \\
\hline $18-30$ & 80 & 40 \\
\hline $31-40$ & 50 & 25 \\
\hline $41-50$ & 40 & 90 \\
\hline $51-60$ & 15 & 25 \\
\hline 61 and above & 15 & 20 \\
\hline Total & 200 & 200 \\
\hline \multicolumn{3}{|l|}{ Educational Qualification } \\
\hline & India & USA \\
\hline Doctorate & 10 & 05 \\
\hline Post graduate & 70 & 15 \\
\hline Graduate & 100 & 40 \\
\hline Higher School & 15 & 80 \\
\hline School/ Elementary & 05 & 60 \\
\hline Total & 200 & 200 \\
\hline \multicolumn{3}{|l|}{ Monthly Income } \\
\hline & India & USA \\
\hline Rs.10001-20000 (for India)/ 1000-2000\$(for USA) & 80 & 20 \\
\hline Rs. $20001-30000$ (for India)/2001-3000\$(for USA) & 40 & 90 \\
\hline Rs.30001-40000 (for India)/3001-4000\$(for USA) & 30 & 50 \\
\hline Rs.40001-5000o(for India) /4001-5000\$(for USA) & 35 & 30 \\
\hline Rs.50001 and above(for India) /5001\$ and above(for USA) & 15 & 10 \\
\hline Total & 200 & 200 \\
\hline
\end{tabular}

